\title{
Economic Analysis of Tomato Cultivation in Kandi Block of West-Bengal, India
}

\author{
Punit Kumar Agarwal* and Arindam Banerjee \\ Ramakrishna Mission Vivekananda University, Ranchi-834008, India \\ *Corresponding author: punitagriculture@gmail.com (ORCID ID: 0000-0001-7208-5507)
}

Received: $11-04-2019$

Revised: $17-07-2019$

Accepted: 23-08-2019

\begin{abstract}
In the present study an attempt has been made to study the economic analysis of tomato cultivation in Kandi block, Murshidabad district, West Bengal. For this 60 tomato growers selected from the study area. The primary data for the agriculture year 2016-17 were collected by personal interviews of the selected farmer, using a multistage sampling method with the help of pre-tested survey schedule. The main objectives were to analyze the cost and return structure of tomato cultivation and to identify the major constraints faced by the farmers in tomato cultivation. The total sample size was 60 . Simple statistical tools like Averages, percentages, cost concepts and garrett ranking were used to interpret the results properly. The overall findings of the study reveal that the cost of cultivation of tomato was ₹ 50879.94 out of which total variable cost was ₹ 40456.52. The net income of the farmers per acre.was ₹ 83385.80. Output in the study area found to be $8853 \mathrm{~kg}$ per acre and cost of production was estimated ₹ $5.74 \mathrm{per} \mathrm{kg}$. The major constraints identified in tomato cultivation were Non availability of institutional support, disease and pest attack, high cost of seeds, high cost of pesticides and high cost of labours during peak season etc.

\section{Highlights}

( West-Bengal has secured first rank in vegetable production and tomato is one of the most consumed vegetable in the study area. The study highlights the cost and return structure of tomato cultivation Seed and labour was the main component of variable cost and the major constraints were Non availability of institutional support, disease and pest attack, high cost of seeds, high cost of pesticides and high cost of labours during peak season.
\end{abstract}

Keywords: Tomato cultivation, Cost and return structure, per acre output, production cost

Agriculture is the backbone of Indian economy. Agriculture plays a crucial role in the livelihood of Indian economy.The share of agriculture during the independence was almost 55 per cent of the National GDP. But it continues showing a decreasing trend with the time, during 1980 it was 42 per cent and now the total contribution of agriculture in GDP of India is approximately 17 per cent. The horticulture products account about 30 per cent of the GDP among agricultural produces. India is now in the first position in the fruit production and it is also the second highest producer of vegetables in the world next only to China. Around 72 per cent of the people of West Bengal are living in the rural areas and agriculture is the main occupation of the state. West Bengal is in the first position for growing the vegetables rather than the other states of Indias. During 2012-13 the total production of vegetables was 26354.61 thousands of MT in net cropping area of 1348 thousands of Ha land which is around 15.71 per cent of the total production in India. The increasing rate of vegetable production is still ongoing in West Bengal. Tomato is one of the most consumed vegetable in India due to its higher nutritive value and organic acid contained. It is also a rich source of vitamin and it has also higher production rate and highly ecological amplitude. It is not only consumed raw, but also it is processed in ketchup sauce, salad, chutney, pickles and also in soups. It is known as the "poor man's orange" as it highly contains vitamin A and vitamin C. Murshidabad is one of the major districts of tomato 
AESRA

Agarwal and Banerjee

producer in West Bengal. The average production rate of tomato is $48.79 \mathrm{qu} / \mathrm{acre}$ in Murshidabad district.

\section{Objective of the Study}

1. To estimate the cost and returns structure of tomato cultivation.

2. To evaluate the constraints faced by the producer during the tomato cultivation process.

\section{Research Methodology}

The study was based on the input and output data obtained from the respondents of the Kandi block. For the selection of the respondents multistage sampling design was employed. In this procedure Murshidabad district of West Bengal was selected purposively at first step. Then the Kandi Block was selected purposively from Murshidabad district on the basis of secondary information. In the third stage, three villages were selected from Kandi block (Baganpara, Durgapur, Mahadia village) based on the higher Tomato growing villages. In the final stage, 20 farmers were selected from each village on the basis of land availability under tomato cultivation. Thus, the total sample size for the present study was 60 .

\section{Type and Source of Data}

For accomplishing the objectives of the study both the primary and secondary data was utilized. Primary data were prevailed from the respondents through personal interview on the basis of the pre structured survey schedule and observation methods for necessary information for the report. The survey schedule included general information related to the respondents, their assets, position, cropping pattern, details of various products like seed, fertilizer, organic manure, plant protection chemicals used in the cultivation process, cultivating practices such as land preparation, transplantation, irrigation, intercultural operation, harvesting along with labour requirement. Information about the hindrances faced by the producer during the cultivation process were also collected.

\section{Analytical Procedure}

The technique of tabular presentation was used to assess the cost, returns and profile of the tomato crop in study area. The percentage and averages were computed and compared to draw meaningful inferences from the raw data.

The cost concept approach is widely used in India for evaluating crop profitability in production. The cost concepts in brief, are Cost A1, A2, B1, B2, C 1, $\mathrm{C} 2$, and Cost $\mathrm{C} 3$

COST A1: This gives the total cash expenses incurred by the owner or operator. It included the following terms of costs.

1. Value of hired human labour.

2. Value of bullock labour.

3. Value of machinery charges (except depreciation).

4. Value of fertilizers and manures.

5. Value of seeds.

6. Value of insecticides, pesticides and weedicide

7. Irrigation charges.

8. Depreciation on farm implements

9. Interest on working capital.

10. Land revenue paid to government.

Cost $\mathbf{A} 2$ = Cost A1+ Rent paid for leased in land, if any

Cost B1 = Cost A1+ Interest on value of owned fixed capital assets.

Cost B2 = Cost B1+ Rental value of owned land less land revenue + rent paid for leased in land.

Cost C1 = Cost B1+ Imputed value of family labour.

Cost C2 $=$ Cost B2+ Imputed value of family labour.

Cost C3 $=$ Cost $\mathrm{C} 2+10 \%$ of Cost C2 on account of managerial functions performed by the farmer.

Gross Income: Yield of main product (in qt./kg) × their prices (₹) + Yield of by product (in qt./kg) and their prices (₹)

Net Income: Gross Income - Cost C.

Farm Business Income: Gross Income - Cost A2

Farm Investment Income: Farm business incomewages of family labour

Family Labour Income: Gross Income - Cost B

For achieving the second objective simply Garret's ranking technique was used 


\section{Garrett's ranking technique}

$$
\text { Percent position }=\frac{100(R i j-0.5)}{N i j}
$$

Where, $R i j$ is the rank given for $i^{\text {th }}$ item by the $J^{\text {th }}$ individual

$N i j$ is the number of items ranked by the $J^{\text {th }}$ individual.

The percent position of each rank was converted in to scores using Garrett table. For each constraint, scores of individual respondents were added together and were divided by total number of respondents for whom scores were added. Thus, mean score for each constraint was ranked by arranging them in descending order.

\section{RESULTS AND DISCUSSION}

The productivity and income from the crop production can be judged in a better way, if we analyse it with respect to the different costs incurred during cultivation of a particular crop. The cost of cultivation and cost of production of any crop is the most important aspect of the farm economy both at micro and macro level point of views; it provides guideline to the government in promulgating the price policy both for factors of production and the produce.

Table 1: Per Acre Input used pattern in tomato cultivation

\begin{tabular}{llcc}
\hline \multirow{2}{*}{ Particulars } & \multicolumn{2}{c}{ Kandi } \\
\cline { 2 - 4 } & Seed & 10789.69 & 21.21 \\
& Urea & 427.14 & 0.84 \\
Variable & DAP & 856.02 & 1.68 \\
Cost & NPK & 3795.18 & 7.46 \\
& Oil Cake & 410.84 & 0.81 \\
& Cow Dung & 302.81 & 0.60 \\
& FYM & 294.15 & 0.58 \\
& Plant Prtotection & 93.09 & 0.18 \\
& Chemical & 1440.12 & 2.83 \\
& Irrigation & 1916.24 & 3.77 \\
& Hired Labour & 2059.83 & 4.05 \\
& Family Labour & 6767.68 & 13.30 \\
& Machinary Labour & 10720.67 & 21.07
\end{tabular}

\begin{tabular}{lccc} 
& $\begin{array}{l}\text { Interest on Working } \\
\text { Capital @ 8\% }\end{array}$ & 583.06 & 1.15 \\
Total Variable Cost & 40456.52 & 79.51 \\
& Land Revenue & 25.00 & 0.05 \\
& $\begin{array}{l}\text { Rental Value of } \\
\text { Land }\end{array}$ & 5000.00 & 9.83 \\
Fixed Cost & $\begin{array}{l}\text { Depreciation } \\
\text { Interest on Fixed }\end{array}$ & 549.98 & 1.08 \\
& $\begin{array}{l}\text { Capital @ 12 \% } \\
\text { Total Fixed Cost }\end{array}$ & 5797.97 & 11.40 \\
& Managerial Cost & 4625.45 & 9.09 \\
Total Cost of Cultivation & $\mathbf{5 0 8 7 9 . 9 4}$ & $\mathbf{1 0 0 . 0 0}$ \\
\hline
\end{tabular}

Source: Field survey.

Table 2: Per Acre various cost concepts used in Tomato cultivation

\begin{tabular}{cc}
\hline Cost & Kandi (₹/acre) \\
\hline A1 & 34263.81 \\
A2 & 34263.81 \\
B1 & 34486.81 \\
B2 & 39486.81 \\
C1 & 41254.50 \\
C2 & 46254.50 \\
C3 & 50879.94 \\
\hline
\end{tabular}

Input wise cost was worked out in two broad heads namely variable cost and fixed cost. The variable cost includes cost of human labour (family and hired), machinery labour, seeds, manures, fertilizers, pesticides, herbicides, and interest on working capital. On the other hand, fixed cost involves land revenues, rental value of owned land and depreciation (Agarwal and Kumar 2017). After analyzing the data it was revealed that the cost of cultivation was ₹ 50879.94 per acre in Kandi block of Murshidabad district. Average variable cost in the study area was ₹ 40456.52 per acre. In terms of percentage it was 79.51 per cent of the total cost. Human labour cost was major variable component in Tomato cultivation which occupying ₹ 8827.51 in Kandi block calculated on the basis of wage rate prevailing in study area. The percentage expenditure incurred on Irrigation component was 3.77 per cent of total cost of cultivation. Land revenue and Rental value of own land was ₹ 25 and ₹ 50,000 per acre. Managerial cost calculated as a fixed cost component that was 9.09 per cent in Kandi block. It was observed at the time of data collection that there 
$\underset{A E S R A}{\mathscr{L}_{1}}$ Agarwal and Banerjee

is no rent paid for leased in land in the study area. So, Cost A1 and Cost A2 were same in Kandi block. The average yield of Tomato cultivation analyzed $8853 \mathrm{~kg}$ per acre in Kandi block. The gross return was calculated from raw data was ₹ 134265.40 per acre. The net income from Tomato cultivation in Kandi block was ₹ 83385.80. Farm business income, farm labour income and farm investment income ₹ 100001.60 , ₹ 94778.63, ₹ 93233.95 per acre were also recorded respectively in Kandi block in Tomato cultivation. Cost of production was ₹ 5.74 per $\mathrm{kg}$ in Kandi block. Benefit-Cost ratio shows the income receives against per rupees investment. The benefit and cost ratio was 2.63 in the studied area (Table 3).
Table 3: Return structure of Tomato cultivation

\begin{tabular}{cc}
\hline Particulars & Kandi \\
\hline Gross Return & 134265.40 \\
Net Income & 83385.80 \\
Farm Business Income & 100001.60 \\
Farm Investment Income & 93233.95 \\
Farm Labour Income & 94778.63 \\
Output (kg) & 8853 \\
Marketing Prices(kg) & 15.16 \\
Cost of Production $(\mathrm{kg})$ & 5.74 \\
B:C ratio & 2.63 \\
\hline
\end{tabular}

Table 4: Prioritization of constraints of tomato cultivation in Kandi Block

\begin{tabular}{|c|c|c|c|c|c|}
\hline \multicolumn{6}{|c|}{ Kandi } \\
\hline S1. No. & Problems & Percent position & Garret Value & Mean Value & Rank \\
\hline 1 & Not Availability Of Seed on time & 8.33 & 77 & 49.75 & III \\
\hline 3 & High cost of Seed & 41.67 & 54 & 44.65 & VI \\
\hline 4 & High cost of pesticide & 58.33 & 46 & 46.38 & IV \\
\hline
\end{tabular}

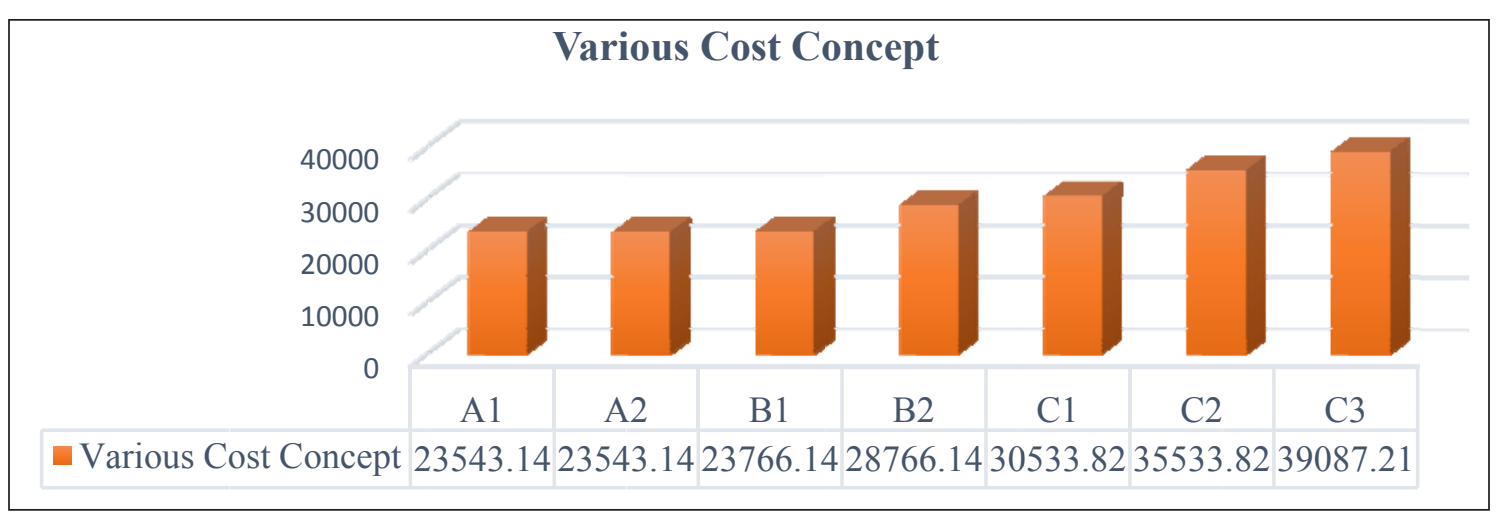

Fig. 1: Per acre various cost concepts used in Tomato Cultivation in Kandi Block

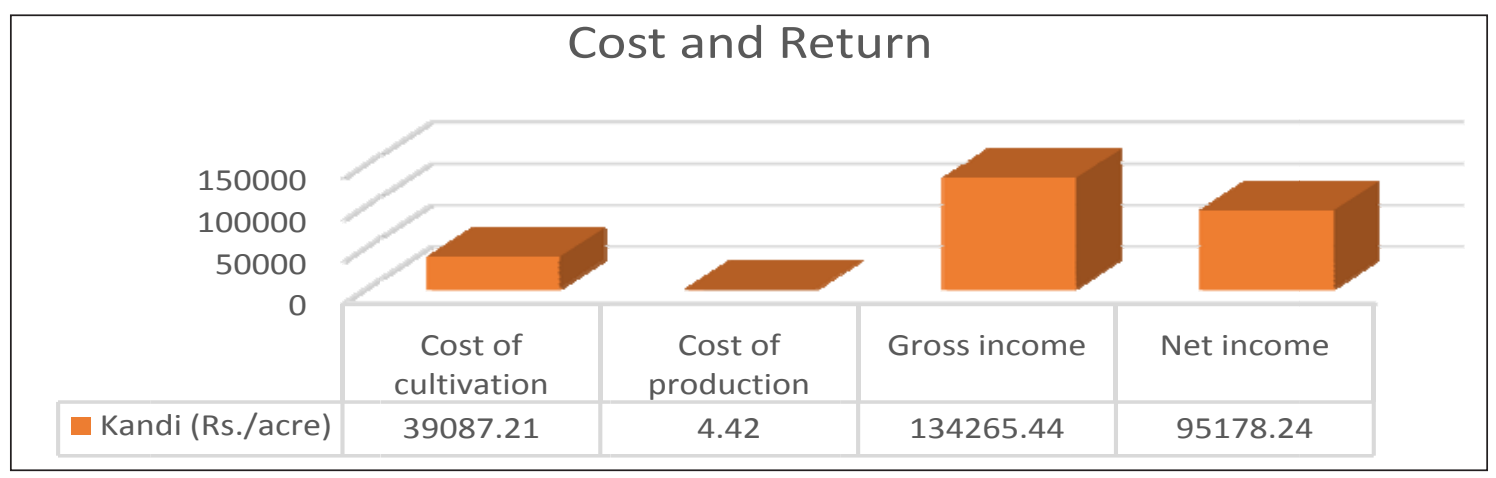

Fig. 2: Return Structure in Kandi Block of Tomato Cultivation 
Tomato crop is grown in two seasons (Rabi and Khaif season) in the study area, Firstly problems were identified on survey basis then ranked them according to Garrett ranking method. High cost of pesticide, lack of irrigation water, high cost of labour, disease and pest attack were some of the main constraints in study area.

The farmers were asked to list priority wise six major constraints they were facing in Kandi Block when doing Tomato cultivation in Kharif season. All these were sorted screened and give them a rank according to the Garrett method.

A perusal of Table 4 revealed that the constraint Non availability of institutional support was the biggest constraint in the study area with the mean score of 60.55 , followed by disease and pest attack with the mean score of 52.88. Not availability of seed on time was the third major constraint in Kandi Block with the mean score of 49.75 . The other constraints expressed by the sample farmers were the high cost of seeds, high cost of pesticides and high cost of labours during peak season.

The livelihood of the people of Kandi block was solely dependent on agriculture. The mostly farmers were belonged from marginal category and having the total land area, less than 2 acre. The farmers cultivated Tomato in the Kharif season at Kandi block which acted as the cash crop for those marginal farmers. Due to the use of high yielding variety seeds in the cultivation process the rate of production was increased which helped them to gain more profit margins. Non availability of institutional support like lack of regulated markets, and lack of presence of co-operative and farmers producers' organizations was the foremost reason behind their loss in the Tomato production process. At the time of data collection it was observed that no tomato processing unit in study area so in my view, there must be a processing unit to check the wastage of the tomatoes at higher rates and Storage facilities should be developed at the main or the submarket areas to check the post distress sell.

\section{REFERENCES}

Agarwal, P.K. and Kumar, A. 2017. A socioeconomic study on pros and cons of SRI method of paddy cultivation in Ormanjhi block of Ranchi district, Jharkhand, India, Indian Journal of Agric. Research, 51(1): 74-77.

Agricultural Statistics at a glance, Department of Agriculture and Cooperation, Ministry of Agriculture, Government of India, 2016 available at http://www.dacnet.nic.in

http://nhb.gov.in/Statistics.aspx? enc=W keg dyuHokljEtehnJoq0KWLU79sOQCy+W4MfOk 01GFOWQSEvtp9tNHHoiv3p49g 
